\title{
An Economic Analysis of Production and Marketing of Vermicompost in Balod District of Chhattisgarh
}

\author{
Siddharth Kumar ${ }^{1}$, A. K. Gauraha ${ }^{1}$, Shashank Sharma ${ }^{2}$ and Shiv Kumar Bhaskar ${ }^{1}$ \\ ${ }^{1}$ Department of Agri-Business and Rural Management, \\ ${ }^{2}$ Department of Agricultural Economics, College of Agriculture, IGKV, Raipur, C.G., India \\ *Corresponding author
}

\section{A B S T R A C T}

Keywords

Vermicompost, respondents, net income, per cubic meter, benefit-cost ratio, reproductive species, earthworm (Eisenia fetida), producergovernment agencies-consumer channel

Article Info

\section{Accepted:}

20 June 2021 Available Online: 10 July 2021
Vermicompost is a biotechnological system. In which earthworms of a specific species are used to convert dung or waste materials into organic materials. Which leads to a great product. Vermicompost's essential ingredients are externally low cost. After which the best products are obtained. The state of Chhattisgarh comprises 28 districts, out of these 28 districts, Balod district comprises 5,669 SHGs and 859 SHG's in Dondi Lohara, which is $15.15 \%$ of the total district of SHGs and hence Balod district will be deliberately selected for the study. There are 5 blocks in Balod district, namely Balod, Dondi, Dondi Lohara, Gunderdehi and Gurur 1 block out of 5 blocks i.e. Dondi Lohara block will be selected from the district as it represents the nearest area from my village. It is observed that an average production of 3.28 quintals per cubic meter is usually done in 3 cycles. The net income per cubic meter at the total cost was Rs. 1520.49. The benefit-cost ratio per cubic meter was 1: 0.61. The total cost per quintal production of vermicompost was Rs 2458.92. Most of the groups are using earthworm (Eisenia fetida) which is highly reproductive species, due to which its use and demand. It was observed that the producer-government agencies-consumer channel has the highest marketing usage compared to others.

\section{Introduction}

Vermi culture enterprise is a relatively new enterprise that is spreading rapidly among women in rural areas. As the vermin culture enterprise is less expensive in terms of costs and relatively more intensive in terms of labour, it provides them with relatively fair employment with less investment.
Vermiculture (from Latin vermes- worms, and culture - farming) has been practiced for at least a hundred years.(Vig. et al., 2005).Earthworms are the inhabitants of earth since pre-Cambrian era, i.e.; about 600 million years ago. They are terrestrial invertebrates belonging to the Order Oligochaeta, Class Chaetopoda, Phylum Annelida (Piearce et al., 1990). This emerging technology is highly 
dependent on the efficiency of earthworms. Thus utilization of vermiculture is one of the important parts to be considered, Vermiculture referred to as the development of mass earthworm culture on compostable or decomposable organic matter. Approximately 4,400 different species of earthworms have been identified worldwide; Eudrillus eugeniae and Eisenia foetida are being used as composting earthworms in most of the countries. Eisenia foetida is perhaps world ${ }^{\text {ee }} \mathrm{s}$ most widely used earthworm for vermicomposting (Krishnamurthy $\mathrm{R} \mathrm{V}$ etal, 1986). The role of earthworm in composting procedure had been mentioned by Charles Darwin (1881) in his book ,Formation of Vegetable Mould. Earthworms are an important link in the food chain of many invertebrate and vertebrate animals (Macdonald 1983).

\section{Materials and Methods}

The state of Chhattisgarh comprises 28 districts, out of these 28 districts, Balod district comprises 5,669 SHGs and 859 SHG's in Dondi Lohara, which is $15.15 \%$ of the total district of SHGs and hence Balod district will be deliberately selected for the study.

There are 5 blocks in Balod district, namely Balod, Dondi, Dondi Lohara, Gunderdehi and Gurur 1 block out of 5 blocks i.e. Dondi Lohara block will be selected from the district as it represents the nearest area from my village.

\section{Primary Data}

Primary data were collected from the sample vermin-compost producers through survey method and personal interview with the help of pre-tested well prepared interview schedules covering various aspects to answer the objectives of this study. The primary data recorded regarding socio-economic characteristics of the vermin-compost producers, farm assets, fixed and variable cost of Vermi-compost production, operation wise labour utilization, total quantity sold, price of vermi compost, agency to whom sold, place of sell and expenditure incurred during marketing of produce etc.

\section{Secondary Data}

The secondary data were collected through various sources like Janpad panchayat Government Site, SHG groups and other NonGovernment organization.

\section{Method of Analysis}

The information collected from the respondents were edited for adequacies and accuracies and cross examined before they were subjected to tubular analysis. The primary data were classified and tabulated in the light of stated objectives of the study and analyzed as per the suitable statistics and economic tools as follow.

\section{Cost concept}

Cost Related To Vermi-compost Production

\section{Cost of cultivation}

Cost of cultivation $=$ Total Fixed Cost + Total Variable Cost

\section{Fixed cost}

Fixed Cost are remaining constant and do not varies with level of production. To calculate fixed cost of production, various cost components are taken into consideration.

\section{Variable cost}

It includes cost of cow dung. earthworm cost, water and electricity charge, labour cost, miscellaneous cost. 


\section{Profitability Concept}

\section{Gross Income}

It is defined as total value of main product

Gross Income $=$ Physical Production $\mathrm{x}$ Price/qt

\section{Net Income}

It is defined as gross income minus total cost

Net Income $=$ Gross Income - Total Cost

Input - Output Ratio

Input - Output Ratio = Gross Income/Total Cost

\section{Benefit - Cost Ratio}

Benefit - Cost Ratio $=$ Net Income/ Total Cost.

\section{Results and Discussion}

To workout cost and returns of vermi compost

\section{Cost of vermi compost(Rs/Quintal)}

Item wise expenditure of vermi compost production was calculated and are presented in Table 4.2.The variable cost are cost that change as the quantity of the good or services that a business produces changes. The total variable cost of Unit-A, Unit-B and Unit-C are Rs.716.89, Rs. 751.67 and Rs. 762.08 Respectively. Total fixed costs include those expenses that do not change within the relevant period as a function of a business's activity. No fixed cost due to government subsidies in all clusters. Whereas, the total cost of Unit-A, Unit-B and Unit-C is Rs
716.89, Rs 715.67 and Rs 762.08. respectively. The total average cost of different physical inputs for units as per the data is Rs.116.59 for culture (Eisenia fetida), Rs.392.85 for cow dung, Rs. 1.02 for electricity \& water, Rs. 144.11 for labor charge, Rs.46.88 for packaging cost, and Rs. 42.07 for Miscellaneous cost.

Gross income is the amount a business earns from the sale of goods or services, before selling, administrative, tax and other expenses have been deducted. The main product income is Rs.1000 and earthworm (Eisenia fetida) sales income is Rs.176.76, Rs.226.75 and Rs.198.41 in Unit-A, Unit-B and Unit-C respectively. The gross income for Unit-A, Unit-B and Unit-C is Rs.1176.75, Rs.1226.75 and Rs.1198.41 respectively. The input-output ratios of Unit-A, Unit-B and Unit-C are $1: 1.64,1: 1.63$ and $1: 1.57$ respectively.

Net income is the amount left after subtracting all costs and expenses from revenue. The net income of Unit-A, Unit-B and Unit-C is Rs.459.87, Rs.475.08, and Rs.436.33 respectively. The Net Profit - Cost Ratio of Unit-A, Unit-B and Unit-C are 1:0.64, 1:0.63 and 1:0.57 respectively. The total average of Gross Income, Input-Output Ratio, Net Income, Net Profit-Cost Ratio for the units is Rs.1198.41, 1:1.61, 455.79 and 1:0.61 respectively.

Total average cost and total average returns of vermi compost (Rs/Quinta)

The estimation revealed that the total raw material quantities in Unit-A, Unit-B and Unit-C were 990 quintal, 630 quintal and 630 quintal respectively. In which the total product quantity received in Unit-A, Unit-B and UnitC were 396 quintal, 220.50 quintal and 252 quintal respectively. 
Table.1 Total cost, gross income and net income of vermi compost production (Rs/ quintal)

\begin{tabular}{|c|c|c|c|c|}
\hline Particulars & Unit-A & Unit-B & Unit-C & Average \\
\hline Variable Cost & & & & \\
\hline Culture (Eisenia fetida) & 121.21 & 95.23 & 133.33 & 116.59 \\
\hline Cow dung & 375 & 428.57 & 375.00 & 392.85 \\
\hline Electricity \& water charges & 0.50 & 1.58 & 0.99 & 1.02 \\
\hline Lebour charge & 128.78 & 161.90 & 141.66 & 144.11 \\
\hline Packaging cost & 48.48 & 32.65 & 59.52 & 46.88 \\
\hline Miscellaneous cost & 42.92 & 31.74 & 51.58 & 42.07 \\
\hline Total variable cost (A) & $\mathbf{7 1 6 . 8 9}$ & $\mathbf{7 5 1 . 6 7}$ & $\mathbf{7 6 2 . 0 8}$ & $\mathbf{7 4 2 . 6 2}$ \\
\hline Fixed Cost & & & & \\
\hline Construction Cost & - & - & - & - \\
\hline Depreciation cost & - & - & - & - \\
\hline Total fixed cost (B) & - & - & - & - \\
\hline Total Cost (A+ B) & $\mathbf{7 1 6 . 8 9}$ & $\mathbf{7 5 1 . 6 7}$ & $\mathbf{7 6 2 . 0 8}$ & $\mathbf{7 4 2 . 6 2}$ \\
\hline Main product return & 1000 & 1000 & 1000 & 1000 \\
\hline Earthworm sale (Eisenia fetida) & 176.76 & 226.75 & 198.41 & 198.41 \\
\hline Gross Income & $\mathbf{1 1 7 6 . 7 6}$ & $\mathbf{1 2 2 6 . 7 5}$ & $\mathbf{1 1 9 8 . 4 1}$ & $\mathbf{1 1 9 8 . 4 1}$ \\
\hline Input-output Ratio & $1: 1.64$ & $1: 1.63$ & $1: 1.57$ & $1: 1.61$ \\
\hline Net Income & $\mathbf{4 5 9 . 8 7}$ & $\mathbf{4 7 5 . 0 8}$ & $\mathbf{4 3 6 . 3 3}$ & $\mathbf{4 5 5 . 7 9}$ \\
\hline Benefit-Cost Ratio & $1: 0.64$ & $1: 0.63$ & $1: 0.57$ & $1: 0.61$ \\
\hline
\end{tabular}

Fig.1 Total cost and net income of vermi compost production (Rs/quintal)

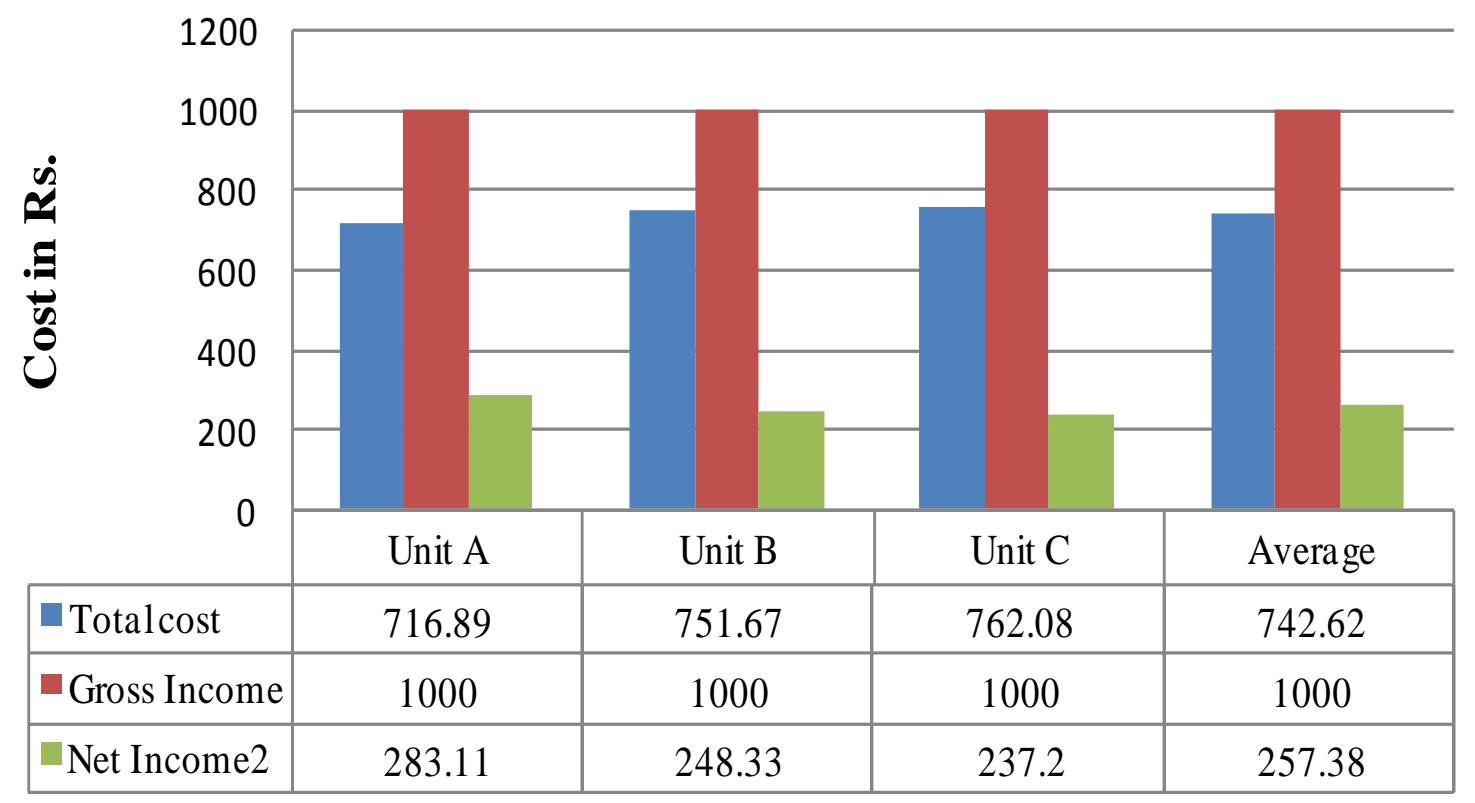


Table.2 Total average cost and total average returns of vermi compost (Rs/Quinta)

\begin{tabular}{|c|c|c|c|c|c|c|}
\hline \multicolumn{7}{|c|}{ Unit - A } \\
\hline & $\begin{array}{l}\text { Quantity } \\
\text { /pit (Qt) }\end{array}$ & $\begin{array}{c}\text { Rate/ } \\
\text { Qt(Rs.) }\end{array}$ & $\begin{array}{c}\text { Total } \\
\text { quantit } \\
\mathbf{y}(\mathbf{Q})\end{array}$ & $\begin{array}{c}\text { Total } \\
\text { amount } \\
(\mathbf{R s})\end{array}$ & $\begin{array}{c}\text { Gross } \\
\text { return (Rs.) }\end{array}$ & $\begin{array}{l}\text { Net income } \\
\text { (Rs) }\end{array}$ \\
\hline Total Cost (Rs) & \multicolumn{5}{|c|}{$2,83,900$} & \\
\hline No of pit(Tank) & \multicolumn{5}{|c|}{30} & \\
\hline Row Material (Qt) & 33.00 & 150 & 990.00 & $1,48,500$ & & \\
\hline Production, $400 \mathrm{~g} / \mathrm{Kg}$ & 13.20 & 1000 & 396.00 & $3,96,000$ & \multirow[t]{2}{*}{$4,66,000$} & \multirow[t]{2}{*}{$1,82,100$} \\
\hline $\begin{array}{c}\text { Earthworm sale } \\
\text { (Rs.) }\end{array}$ & - & 200 & 3.5 & 70,000 & & \\
\hline \multicolumn{7}{|c|}{ Unit - B } \\
\hline & $\begin{array}{l}\text { Quantity } \\
\text { /pit (Qt) }\end{array}$ & $\begin{array}{c}\text { Rate/ } \\
\text { Qt(Rs.) }\end{array}$ & $\begin{array}{c}\text { Total } \\
\text { quantit } \\
\mathbf{y}(\mathbf{Q})\end{array}$ & $\begin{array}{c}\text { Total } \\
\text { amount } \\
(\mathbf{R s})\end{array}$ & $\begin{array}{c}\text { Gross } \\
\text { return (Rs.) }\end{array}$ & $\begin{array}{l}\text { Net income } \\
\text { (Rs) }\end{array}$ \\
\hline Total Cost (Rs) & \multicolumn{5}{|c|}{$\mathbf{1 , 5 9 , 7 5 0}$} & \\
\hline No of pit(Tank) & \multicolumn{5}{|c|}{21} & \\
\hline Row Material & 30.00 & 150 & 630.00 & 94,500 & & \\
\hline Production,350g/Kg & 10.50 & 1000 & 220.50 & $2,20,500$ & \multirow{2}{*}{$2,70,500$} & \multirow{2}{*}{$1,10,750$} \\
\hline Earthworm sale & & 200 & 2.5 & 50,000 & & \\
\hline \multicolumn{7}{|c|}{ Unit - C } \\
\hline & $\begin{array}{l}\text { Quantity } \\
\text { /pit (Qt) }\end{array}$ & $\begin{array}{c}\text { Rate/ } \\
\text { Qt(Rs.) }\end{array}$ & $\begin{array}{c}\text { Total } \\
\text { quantit } \\
\mathbf{y}(\mathbf{Q})\end{array}$ & $\begin{array}{c}\text { Total } \\
\text { amount } \\
(\mathrm{Rs})\end{array}$ & $\begin{array}{c}\text { Gross } \\
\text { return (Rs.) }\end{array}$ & $\begin{array}{l}\text { Net income } \\
\text { (Rs) }\end{array}$ \\
\hline Total Cost (Rs) & \multicolumn{5}{|c|}{$1,92,050$} & \\
\hline No of pit(Tank) & \multicolumn{5}{|c|}{21} & \\
\hline Row Material & 30.00 & 150 & 630.00 & 94,500 & & \\
\hline Production, $400 \mathrm{~g} / \mathrm{Kg}$ & 12.00 & 1000 & 252.00 & $2,52,000$ & \multirow[t]{2}{*}{$3,02,000$} & \multirow[t]{2}{*}{$1,09,950$} \\
\hline Earthworm sale & & 200 & 2.5 & 50,000 & & \\
\hline \multicolumn{7}{|c|}{ Average } \\
\hline & $\begin{array}{l}\text { Quantity } \\
\text { /pit (Qt) }\end{array}$ & $\begin{array}{c}\text { Rate/ } \\
\text { Qt(Rs.) }\end{array}$ & $\begin{array}{c}\text { Total } \\
\text { quantit } \\
\mathbf{y}(\mathbf{Q t})\end{array}$ & $\begin{array}{c}\text { Total } \\
\text { amount } \\
(\text { Rs })\end{array}$ & $\begin{array}{c}\text { Gross } \\
\text { return (Rs.) }\end{array}$ & $\begin{array}{l}\text { Net income } \\
\text { (Rs) }\end{array}$ \\
\hline Total Cost (Rs) & \multicolumn{5}{|c|}{$2,13,899.99$} & \\
\hline No of pit(Tank) & \multicolumn{5}{|c|}{24} & \\
\hline Row Material & 31.00 & 150 & 744.00 & $1,11,600$ & \multirow{3}{*}{$3,46,166.66$} & \\
\hline $\begin{array}{l}\text { Production, } \\
\text { 383.85g/Kg }\end{array}$ & 11.90 & 1000 & 285.60 & $2,89,500$ & & \multirow[t]{2}{*}{$1,32,266.66$} \\
\hline Earthworm sale & & 200 & 283.33 & $56,666.66$ & & \\
\hline
\end{tabular}


Table.3 Total Net income of per capita/year/day (Rs.)

\begin{tabular}{|c|c|c|c|c|c|}
\hline S.No. & Particular & Unit-A & Unit-B & Unit-C & Average \\
\hline $\mathbf{1 .}$ & Working day & 20 & 20 & 20 & 20 \\
\hline $\mathbf{2 .}$ & Total compost cycle & 3 & 3 & 3 & 3 \\
\hline $\mathbf{3 .}$ & Total working day & 60 & 60 & 60 & 60 \\
\hline $\mathbf{4 .}$ & No of labor & 8 & 10 & 5 & 7.67 \\
\hline $\mathbf{5 .}$ & Total day of work through total labor & 480 & 600 & 300 & 460 \\
\hline $\mathbf{6 .}$ & Total net income & $\mathbf{1 , 8 2 , 1 0 0}$ & $\mathbf{1 , 1 0 , 7 5 0}$ & $\mathbf{1 , 0 9 , 9 5 0}$ & $\mathbf{1 , 3 2 , 2 6 6 . 6 6}$ \\
\hline $\mathbf{7 .}$ & Net income/capita/year & 3,035 & $1,845.83$ & $1,832.50$ & $2,204.44$ \\
\hline $\mathbf{8 .}$ & Net income/capita/day & $\mathbf{3 7 9 . 3 8}$ & $\mathbf{1 8 4 . 5 8}$ & $\mathbf{3 6 6 . 5 0}$ & $\mathbf{2 8 7 . 5}$ \\
\hline
\end{tabular}

Fig.2 Total average cost and total average returns of vermi compost in quintal

\section{Total Row material and total Production in quintal}

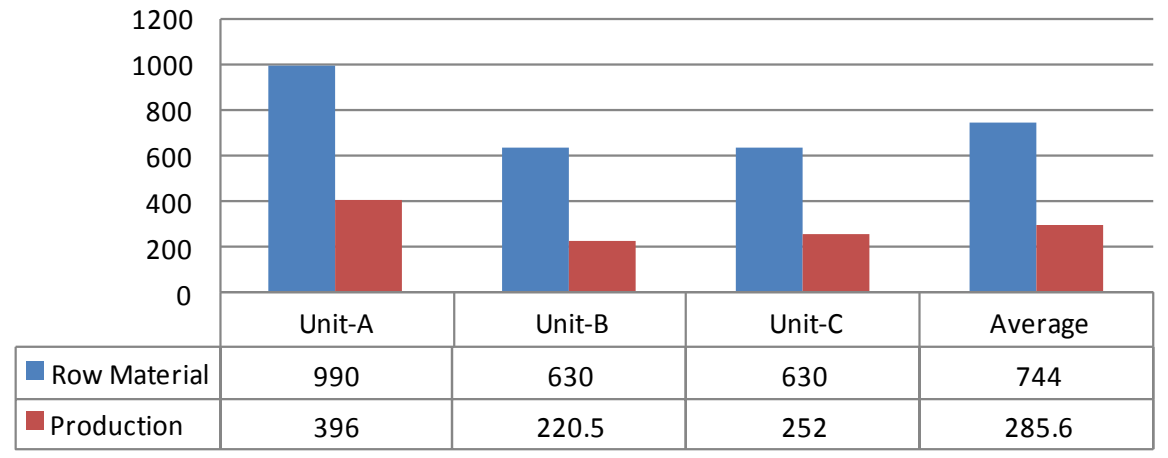

Fig.3 Total Net income of per capita/year/day (Rs.)

\begin{tabular}{|c|c|c|c|c|}
\hline \multicolumn{5}{|c|}{ Per capita income ( $\mathbf{R s .}$ ) } \\
\hline \multicolumn{5}{|l|}{200000} \\
\hline \multicolumn{5}{|l|}{150000} \\
\hline \multicolumn{5}{|l|}{100000} \\
\hline \multicolumn{5}{|l|}{50000} \\
\hline 0 & Unit-A & Unit-B & Unit-C & Avarage \\
\hline Total Net income & 182100 & 110750 & 109950 & 132266.66 \\
\hline Toatal Net incone/Capita/Year & 3035 & 1845.83 & 1832.5 & 2204.44 \\
\hline Toatal Net incone/Capita/Day & 379.38 & 184.58 & 366.5 & 287.5 \\
\hline
\end{tabular}


The total average raw material quantity in the calculation obtained was 744 quintals and the total average product of raw materials was 285.60 quintals. The details of which are given in Table 4.3.

\section{Total Net income of per capita/year/day (Rs.)}

From the calculations it was found that the annual per capita income in the groups UnitA, Unit-B and Unit-C respectively is Rs.3035,1845. Rs. 1832. Rs. and unit-A, unit$B$ and unit-C of unit-A, unit-B and unit-C in per capita income of Rs.379. Rs.184. and Rs.366. respectively. Full details of which are in Table 4.4. The total cost per quintal production of vermi compost was Rs. 742.62

The average main product returns was Rs.1000 and earthworm (Eisenia fetida) sale return was Rs.198.41.

The net income per quintal vermi compost production at the total cost was Rs 455.79. The average profit-cost ratio per quintal was (1: 0.61).

\section{Suggestions}

Establishment of high quality earthworm production units in clusters and availability of best quality species such as red wigglers (Eisenia fetida) and redworm (Lumbricus rubellas). Adequate financial support will be provided by state-run banks or other financial institutions under initial vermicompost construction.

\section{References}

Ranwa, R. S. and Singh, K. P., Effect of integrated nutrient management with vermicompost on productivity of wheat (Triticum aestivum), Indian J. Agron., 44, 554-559 (1999).

Saxena, A. K. and R. A. Singh, 2000. Economics efficiency in vermicompost business system of mahakoshal region in M.P. Indian I. of Agril. Econ., 48 (4) : 148-151.

Reddy B V, Honnaiah C, Reddy P N S, Kale R D, Balakrishna A N (2009). "Economics of vermicompost production and marketing in Southern Karnataka", Mysore J. Agric. Sci., Vol. 43, No. 1, pp. 125-131.

Shivakumara C (2008). "Production and marketing of vermicompost in Karnataka: A case of Dharwad district", unpublished M.Sc. Thesis. University of Agricultural Sciences, Dharwad, Karnataka, India.

Devkota, D. (2014). "Economics of Production and Marketing of Vermicompost in Chitwan, Nepal" International Journal of Agricultural and Soil Science (ISSN: 2315-9989) Vol. 2(7) pp. 112-117,

Mariappan T., Vijayalakshmi K., "Vermicomposting : A possible small scale industry", G.S. International Journal of current Research Volume. 11, December 2010.

\section{How to cite this article:}

Siddharth Kumar, A. K. Gauraha, Shashank Sharma and Shiv Kumar Bhaskar. 2021. An Economic Analysis of Production and Marketing of Vermicompost in Balod District of Chhattisgarh. Int.J.Curr.Microbiol.App.Sci. 10(07): 532-538. doi: https://doi.org/10.20546/ijcmas.2021.1007.058 